\title{
Intake, apparent digestibility, rumen fermentation and nitrogen efficiency in sheep fed a tropical legume silage with or without concentrate
}

\author{
LEANDRO D. DA SILVA ${ }^{1,2}$, ODILON G. PEREIRA ${ }^{1}$, THIAGO C. DA SILVA ${ }^{3}$, SEBASTIÃO \\ C. VALADARES FILHO ${ }^{1}$, KARINA G. RIBEIRO ${ }^{1}$ and STEFANIE A. SANTOS ${ }^{4}$ \\ ${ }^{\text {I}}$ Departamento de Zootecnia, Universidade Federal de Viçosa, Av. P.H. Rolfs, s/n, 36570-000 Viçosa, MG, Brazil \\ ${ }^{2}$ Departamento de Zootecnia, Universidade Federal dos Vales do Jequitinhonha e Mucuri, Campus \\ JK, Rodovia BR 367, 5000, Alto da Jacuba, 39100-000 Diamantina, MG, Brazil \\ ${ }^{3}$ Departamento de Zootecnia, Universidade Federal de Goiás, Av. Esperança, \\ s/n, Campus Samambaia, 74690-900 Goiânia, GO, Brazil \\ ${ }^{4}$ Departamento de Zootecnia, Universidade Federal da Bahia, Rua Adhemar \\ de Barros, 500, Ondina, 40170-110 Salvador, BA, Brazil
}

Manuscript received on January 16, accepted for publication on April 12, 2018

\begin{abstract}
Legume silage can increase the forage quality of the diets as well as supply it with nitrogen, calcium and phosphorus. The objective was to evaluate the intake, apparent digestibility, rumen fermentation and nitrogen efficiency in sheep fed a tropical legume silage with or without concentrate. Twelve crossbred sheep with an average initial body weight of $32.2 \pm 1.26 \mathrm{~kg}$, with six animals cannulated in the rumen were distributed into four $3 \times 3$ Latin squares. The treatments were 1) Stylosanthes silage without concentrate (StS), 2) Stylosanthes silage with concentrate $(\mathrm{StS}+\mathrm{C})$, and 3) corn silage with concentrate $(\mathrm{CS}+\mathrm{C})$. StS diet showed lowest intake, except for neutral detergent fiber (NDF). The diets $\mathrm{StS}+\mathrm{C}$ and $\mathrm{CS}+\mathrm{C}$ showed similar intake of dry matter (DM) and crude protein. The intake of total digestible nutrients was higher for $\mathrm{CS}+\mathrm{C}$ diet than diets $\mathrm{StS}+\mathrm{C}$ and $\mathrm{StS}$. Animals fed $\mathrm{CS}+\mathrm{C}$ diet had lowest ruminal $\mathrm{pH}$. The nitrogen use efficiency was similar for the diets with concentrate. In conclusion, $\mathrm{StS}+\mathrm{C}$ diet replacing $\mathrm{CS}+\mathrm{C}$ diet decreases the intake of total digestible nutrients.
\end{abstract}

Key words: alternative foods, corn silage, crude protein, neutral detergent fiber, Stylosanthes.

\section{INTRODUCTION}

Legume silage for livestock systems it is interesting because is an excellent source of protein and the crop requires less use of nitrogen fertilizers than grasses (Heinritz et al. 2012). In addition, sources of protein used in feedlot diets have high cost, like soybean meal (Millen et al. 2009). Thus, legume

Correspondence to: Leandro Diego da Silva

E-mail: leandro.silva@ufv.br silage can reduce the cost of diet as well as supply it with nitrogen, calcium and phosphorus (Baxter et al. 1984).

Stylosanthes cv. Campo Grande (stylo; Stylosanthes macrocephala and S. capitata) is a legume developed in Brazil. This cultivar showed good adaptation to infertile soils, mainly sandy soils, and with an annual production of 8-15 ton of $\mathrm{DM} \mathrm{ha}^{-1}$ (Fernandes et al. 2005, Moreira et al. 2015). In addition, recent studies with Stylosanthes 
cv. Campo Grande have shown that it is possible to obtain well-fermented silage when harvested at the time of flowering. This legume silage stabilizes with $\mathrm{pH} 4$, and lactic acid and acetic acid concentrations of 5 and $3.6 \%$, respectively, and concentration of ammonia around $10 \%$ of total nitrogen, being able to replace corn silage in diets of feedlot beef cattle without affecting feed intake or performance (Souza et al. 2014, Silva et al. 2016, Silva et al. 2017).

Therefore, it was hypothesized that stylo silage (StS) could replace corn silage (CS) in diets for sheep. The intake and digestibility of nutrients, ruminal ammonia-nitrogen $\left(\mathrm{NH}_{3}-\mathrm{N}\right)$, ruminal $\mathrm{pH}$, and nitrogen balance were evaluated in sheep fed diets containing StS with and without concentrate and corn silage with concentrate.

\section{MATERIALS AND METHODS}

The experiment was conducted at the Animal Science Department of the Federal University of Viçosa (UFV) following the procedures for humanitarian animal care and management guidelines from the ethics committee at the UFV.

\section{EXPERIMENTAL PROCEDURE}

Stylo and corn plants were harvested at the pre-blooming stage and one-third milk-line, respectively. Crops were chopped using a stationary chopper ( $2 \mathrm{~mm}$ theoretical chop length) and packed in laboratory-scale silos with capacity of $550 \mathrm{~kg}$, with a packing density of $550 \mathrm{~kg} / \mathrm{m}^{3}$.

Treatments consisted of diets containing stylo silage without $(\mathrm{StS})$ or with concentrate $(\mathrm{StS}+\mathrm{C})$ and corn silage with concentrate $(\mathrm{CS}+\mathrm{C})$. The forage:concentrate ratio was 50:50 on a DM basis. Concentrate was made with ground corn and soybean meal.

Diets were formulated according to the amount of crude protein (CP) of StS, $117 \mathrm{~g} / \mathrm{kg}$ of DM. The mixture of urea and ammonium sulfate $(9: 1)$ was used to adjust the $\mathrm{CP}$ content of corn silage
(Table I). The mineral mix was offered ad libitum in feeders adapted in the cages.

Twelve crossbred sheep (predominantly Santa Inês) with average initial body weight of $32.2 \pm$ $1.26 \mathrm{~kg}$, six of which were rumen-cannulated. The animals were housed in a covered barn in individual cages equipped with feeders and drinking water systems. The animals were fed twice daily at 0800 $\mathrm{h}$ and $1600 \mathrm{~h}$ for ad libitum intake, allowing for a maximum of $15 \%$ orts.

Each experimental period lasted 16 days, with 11 days for adaptation and five days for samples and data collections. The animals were weighed at the beginning and at the end of each experimental period. Total collections of orts, feces and urine were performed during the first four days of each sampling period. Leather bags were used for the

TABLE I

Proportion of ingredients and chemical composition of the diets (g/kg of dry matter).

\begin{tabular}{|c|c|c|c|}
\hline \multirow{2}{*}{ Items } & \multicolumn{3}{|c|}{ Treatments $^{1}$} \\
\hline & StS & $\mathrm{StS}+\mathrm{C}$ & $\mathrm{CS}+\mathrm{C}$ \\
\hline \multicolumn{4}{|l|}{ Proportion of ingredients } \\
\hline Stylosanthes silage & 1000 & 500 & - \\
\hline Corn silage & - & - & 500 \\
\hline Ground corn & - & 458 & 454 \\
\hline Soybean meal & - & 36.6 & 36.2 \\
\hline Urea/ammonium sulfate $(9: 1)$ & - & - & 5.00 \\
\hline Sodium bicarbonate & - & 5.00 & 5.00 \\
\hline \multicolumn{4}{|l|}{ Chemical composition } \\
\hline Dry matter, g/kg & 291 & 582 & 589 \\
\hline Organic matter & 914 & 946 & 963 \\
\hline Ether extract & 28.6 & 32.0 & 28.9 \\
\hline Crude protein & 117 & 118 & 114 \\
\hline Neutral detergent fiber & 643 & 394 & 331 \\
\hline Acid detergent fiber & 504 & 275 & 208 \\
\hline $\begin{array}{l}\text { Indigestible neutral detergent } \\
\text { fiber }\end{array}$ & 351 & 181 & 98.6 \\
\hline Non-fiber carbohydrates & 125 & 401 & 503 \\
\hline Lignin & 140 & 79.2 & 30.6 \\
\hline
\end{tabular}


fecal collection and at the end of each experimental period a fresh sample of approximately $350 \mathrm{~g}$ per animal was stored. Urine collection was performed using collector funnels that were attached to the cages and drained into a bucket on the ground containing $100 \mathrm{~mL}$ of $20 \%$ (v/v) sulfuric acid. After $24 \mathrm{~h}$, the weight and the total volume of urine were recorded, and an aliquot of $5 \%$ of the daily volume was stored in a freezer. A composite sample was made for each animal after four days of collection.

To determine ruminal $\mathrm{pH}$ and $\mathrm{NH}_{3}-\mathrm{N}$ concentration, samples were taken on the fifth day of each sampling period, prior to feeding and 2, 4 and $6 \mathrm{~h}$ after feeding. Approximately $50 \mathrm{~mL}$ of rumen fluid was collected through of rumen cannula and the $\mathrm{pH}$ was immediately determined using a digital $\mathrm{pH}$ meter. After measuring $\mathrm{pH}, 1 \mathrm{~mL}$ of a $50 \%$ sulfuric acid (v/v) solution was added to each sample and were stored at $-15^{\circ} \mathrm{C}$ for subsequent analysis of $\mathrm{NH}_{3}-\mathrm{N}$ concentration.

\section{LABORATORY ANALYSIS}

Samples of feed, orts, and feces were dried at $55^{\circ} \mathrm{C}$ for $72 \mathrm{~h}$ in a forced air oven and ground in a Wiley mill (Wiley mill, Arthur H. Thomas, PA, USA) with a 1-mm screen. The contents of DM, organic matter $(\mathrm{OM})$, crude protein $(\mathrm{CP})$, ether extract (EE), and acid detergent fiber (ADF) were determined according to AOAC (1990); neutral detergent fiber (NDF; Mertens 2002), sulfuric acid lignin (Robertson and Van Soest 1981) and indigestible neutral detergent fiber (Huhtanen et al. 1994) were also measured. Ruminal $\mathrm{NH}_{3}-\mathrm{N}$ was determined using a colorimetric method according to Chaney and Marbach (1962). The concentrations of non-fibrous carbohydrates (NFC; Detmann and Valadares Filho 2010), total digestible nutrients (TDN; Weiss 1999) and metabolizable energy (ME; NRC 2001) were calculated.

Urine samples were analyzed for creatinine using the Picrate Alkaline method (Labtest
Diagnóstica, MG, Brazil) and urea by the enzymatic-colorimetric method (Urea CE; Labtest Diagnóstica).

\section{STATISTICAL ANALYSIS}

Data were analyzed using the MIXED procedure of SAS (Statistical Analysis Software, Inc., Cary, $\mathrm{NC}$ ), based on four $3 \times 3$ Latin square design and balanced for the residual effects of treatments (Lucas 1957). Two Latin squares were with rumencannulated animals and the two others with animals without cannula. The effects of the model were the experimental diets as fixed effects and Latin square, animal and experimental periods as random effects. Ruminal $\mathrm{pH}$ and concentration of $\mathrm{NH}_{3}-\mathrm{N}$ were analyzed through PROC REG; the diet (D), the sampling time $(\mathrm{T})$ and the interaction between them $(\mathrm{D} \times \mathrm{T})$ were considered to be as fixed effects. The scheme of repeated measures was used, where sampling times $(0,2,4$, and 6 hours after feeding) were repeated for each experimental unit (Kaps and Lamberson 2004). Data were submitted to the analysis of variance and Tukey-test was used for comparisons of the means. All statistical procedures were performed using 0.05 as the critical probability level for type I error.

\section{RESULTS}

Nutrients intake, except NDF, were lower for StS diet. The intake of DM, OM, EE, and CP were higher for diets containing concentrate. The $\mathrm{CS}+\mathrm{C}$ diet showed lower NDF intake than the diets $\mathrm{StS}+\mathrm{C}$ and StS. The TDN intake was higher for the $\mathrm{CS}+\mathrm{C}$ diet than the diets $\mathrm{StS}+\mathrm{C}$ and $\mathrm{StS}$ (Table II).

Apparent digestibility of NDF was not affected by the diets. Digestibility of DM, OM, CP and dietary contents of TDN and ME were higher for the diet $\mathrm{CS}+\mathrm{C}$ than the diets $\mathrm{StS}+\mathrm{C}$ and $\mathrm{StS}$. The StS diet showed the lowest apparent digestibility of DM, OM, CP and lowest dietary contents of TDN and ME (Table II). 
TABLE II

Nutrient intake, total apparent digestibility, and nitrogen efficiency of sheep fed Stylosanthes silage without concentrate (StS), Stylosanthes silage with concentrate $(\mathrm{StS}+\mathrm{C})$, and corn silage with concentrate $(\mathrm{CS}+\mathrm{C})$.

\begin{tabular}{|c|c|c|c|c|}
\hline \multirow{2}{*}{ Items } & \multicolumn{3}{|c|}{ Treatments } & \multirow{2}{*}{ SEM $^{1}$} \\
\hline & StS & $\mathrm{StS}+\mathrm{C}$ & $\mathrm{CS}+\mathrm{C}$ & \\
\hline \multicolumn{5}{|l|}{ Intake, g/day } \\
\hline Dry matter & $528 b$ & $907 \mathrm{a}$ & $988 \mathrm{a}$ & 72.8 \\
\hline Organic matter & $480 \mathrm{~b}$ & $860 \mathrm{a}$ & $962 \mathrm{a}$ & 69.3 \\
\hline Ether extract & $16.8 \mathrm{~b}$ & $25.5 \mathrm{a}$ & $25.2 \mathrm{a}$ & 3.50 \\
\hline Crude protein & $64.7 b$ & $110 \mathrm{a}$ & $112 \mathrm{a}$ & 8.54 \\
\hline Neutral detergent fiber & $344 \mathrm{a}$ & $346 \mathrm{a}$ & $304 b$ & 31.7 \\
\hline Total digestible nutrients & $238 \mathrm{c}$ & $586 b$ & $749 \mathrm{a}$ & 48.5 \\
\hline \multicolumn{5}{|l|}{ Intake, $\mathrm{g} / \mathrm{kg}$ of body weight } \\
\hline Dry matter & $16.5 b$ & $27.4 \mathrm{a}$ & $29.0 \mathrm{a}$ & 1.56 \\
\hline Neutral detergent fiber & $10.7 \mathrm{a}$ & $10.4 \mathrm{a}$ & $8.91 b$ & 0.77 \\
\hline \multicolumn{5}{|l|}{ Digestibility, $\mathrm{g} / \mathrm{kg}$ of dry matter } \\
\hline Dry matter & $385 \mathrm{c}$ & $620 \mathrm{~b}$ & $711 \mathrm{a}$ & 30.2 \\
\hline Organic matter & $453 c$ & $663 b$ & $744 a$ & 25.2 \\
\hline Crude protein & $519 \mathrm{c}$ & $612 b$ & $662 \mathrm{a}$ & 17.4 \\
\hline Neutral detergent fiber & 465 & 472 & 519 & 29.6 \\
\hline Total digestible nutrients & $449 \mathrm{c}$ & $653 b$ & $762 \mathrm{a}$ & 21.6 \\
\hline \multicolumn{5}{|l|}{ Energy content, Mcal $/ \mathrm{kg}$ of dry matter } \\
\hline Metabolizable & $1.58 \mathrm{c}$ & $2.12 b$ & $2.53 \mathrm{a}$ & 0.08 \\
\hline \multicolumn{5}{|l|}{ Nitrogen use efficiency, g/day } \\
\hline Nitrogen intake & $10.2 b$ & $17.6 \mathrm{a}$ & $18.5 \mathrm{a}$ & 1.28 \\
\hline Nitrogen feces & $4.84 b$ & $6.98 \mathrm{a}$ & $6.59 \mathrm{a}$ & 0.58 \\
\hline Nitrogen urine & 6.39 & 7.18 & 7.45 & 0.79 \\
\hline Nitrogen balance & $-1.04 b$ & $3.48 \mathrm{a}$ & $4.46 \mathrm{a}$ & 0.82 \\
\hline Urinary urea nitrogen & 3.78 & 3.62 & 4.55 & 0.51 \\
\hline Creatinine, $\mathrm{mg} / \mathrm{kg}$ of body weight & 28.6 & 26.2 & 29.6 & 2.98 \\
\hline
\end{tabular}

Means followed by the same letter in the rows are not significantly different based on a Tukey-test $(\mathrm{P}<0.05)$. ${ }^{1} \mathrm{SEM}$ : standard error of the mean.

Animal fed StS diet showed lowest N-intake, $\mathrm{N}$-feces, and $\mathrm{N}$-balance than the diets with concentrate. Urinary excretion of nitrogen, urea nitrogen and creatinine were not affected by the treatments. The diets $\mathrm{StS}+\mathrm{C}$ and $\mathrm{CS}+\mathrm{C}$ had similar $\mathrm{N}$-intake, N-feces, and N-balance (Table II).

Ruminal $\mathrm{pH}$ and $\mathrm{NH}_{3}-\mathrm{N}$ were affected by the interaction between diets and sampling time. The $\mathrm{pH}$ decreased faster for the $\mathrm{CS}+\mathrm{C}$ diet than the diets $\mathrm{StS}+\mathrm{C}$ and $\mathrm{StS}$. The effect of diets was significantly for ruminal $\mathrm{pH}$, with averages $6.22,6.42$ and 6.85 for $\mathrm{CS}+\mathrm{C}, \mathrm{StS}+\mathrm{C}$ and $\mathrm{StS}$, respectively (Figure 1).
Animal fed StS diet showed higher ruminal $\mathrm{NH}_{3}-\mathrm{N}$ four and six hours after feeding (Figure 2).

\section{DISCUSSION}

Low DM intake for StS diet agrees with estimated intake by NRC (2007) for maintenance of sheep. Probably the NDF intake was a limiting factor and resulted in lower TDN intake for StS diet. Since the NDF intake was similar between $\mathrm{StS}$ and $\mathrm{StS}+\mathrm{C}$ and the last had similar DM intake than the $\mathrm{CS}+\mathrm{C}$ diet. High lignin content and consequently iNDF could 


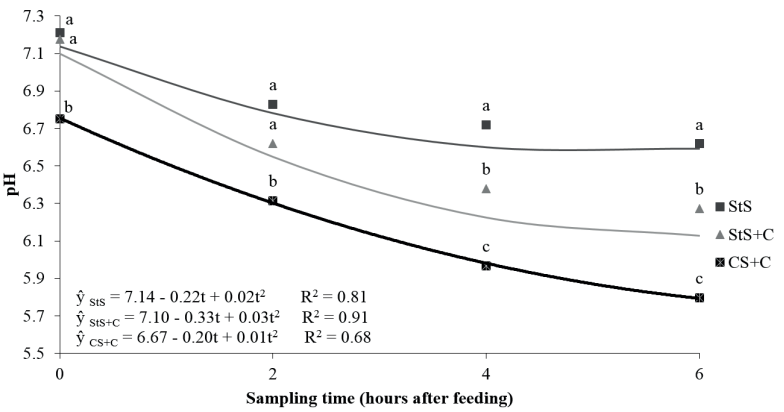

Figure 1 - Ruminal $\mathrm{pH}$ as a function of sampling time of sheep fed Stylosanthes silage without concentrate (StS), Stylosanthes silage with concentrate $(\mathrm{StS}+\mathrm{C})$, and corn silage with concentrate $(\mathrm{CS}+\mathrm{C})$. Different letter in the points are significantly based on a Tukey-test $(\mathrm{P}<0.05)$. Effects of diets $(\mathrm{P}<0.01)$, time $(\mathrm{P}<0.01)$ and interaction $(\mathrm{P}=0.04)$; standard error of mean (0.05).

explain the difference on TDN intake, as previously observed in other study with sheep (Silva et al. 2015). These fractions are related with decrease of intake by the ruminants. Intake restriction on diets containing high fiber content is mainly due the physical factors, which depends on the filling rumen capacity and on the fiber digestibility (Mertens 1994). Silage quality characteristics such as the $\mathrm{pH}$, the concentrations of lactic acid, acetic acid, butyric acid and $\mathrm{NH}_{3}-\mathrm{N}$ are known to impair feed intake, however, in small ruminants, dietary NDF seems to be the main determinant for voluntary intake (Castro-Montoya and Dickhoefer 2018).

Although the $\mathrm{StS}+\mathrm{C}$ diet showed higher digestibility than $\mathrm{StS}$ diet, the highest digestibility values were for $\mathrm{CS}+\mathrm{C}$ diet. Probably due to the high lignin content of StS that acts as a barrier for the ruminal microorganisms during the fiber colonization and digestion. Because of that, diets $\mathrm{StS}$ and $\mathrm{StS}+\mathrm{C}$ showed lower content of TDN than $\mathrm{CS}+\mathrm{C}$ diet. The lack of effect on NDF digestibility among the diets could be due the diets with high NDF content and longer retention can decrease the intake and increase the digestibility, as previously observed in other studies with sheep (Mupangwa et al. 2000, Van Soest 1994).

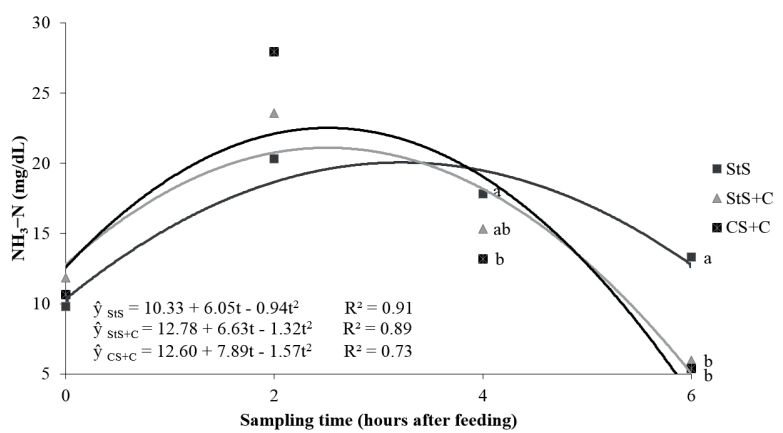

Figure 2 - Concentration of ruminal ammonia nitrogen $\left(\mathrm{NH}_{3}-\mathrm{N}\right)$ as a function of sampling time of sheep fed Stylosanthes silage without concentrate (StS), Stylosanthes silage with concentrate $(\mathrm{StS}+\mathrm{C})$ and corn silage with concentrate $(\mathrm{CS}+\mathrm{C})$. Different letter in the points are significantly based on a Tukeytest $(\mathrm{P}<0.05)$. Effects of diets $(\mathrm{P}=0.78)$, time $(\mathrm{P}<0.01)$ and its interaction $(\mathrm{P}<0.01)$; standard error of mean $(0.96)$.

Ruminal $\mathrm{pH}$ for the diets $\mathrm{StS}$ and $\mathrm{StS}+\mathrm{C}$ decreased more slowly than $\mathrm{CS}+\mathrm{C}$ diet, probably due lower digestibility and rumen production of organic acids, besides of higher buffering capacity of legume silages (Heinritz et al. 2012). Generally, ruminal $\mathrm{pH}$ affects directly the growth rate of ruminal microorganisms and diets with high proportion of roughage can increase the ruminal $\mathrm{pH}$ and improve the cellulolytic bacteria growth due the pattern of replacing the soluble carbohydrates by NDF (Church 1979, Van Soest 1994).

In this study, for StS diet, the pattern of ruminal $\mathrm{NH}_{3}-\mathrm{N}$ four and six hours after feed supply, show an imbalance for microbial growth between degradation rate of protein and energy, therefore, without energy in the rumen, the concentration of $\mathrm{NH}_{3}-\mathrm{N}$ can increase. In addition, the concentrate can improve nitrogen intake, digestion and retention due the accord with the dietary energy and nitrogen supply to the microbial growth (Van Soest 1994). Probably the imbalance between energy and protein resulted an excess of $\mathrm{NH}_{3}-\mathrm{N}$ in the rumen that was absorbed through the rumen wall. This $\mathrm{NH}_{3}-\mathrm{N}$ is converted into urea and can return to the rumen or may be eliminated in the urine (Poppi and McLennan 1995). Furthermore, urea excretion in urine is greater when in the 
rumen the protein degradation rate exceeds the fermentation of carbohydrates, with consequent urea production and excretion, resulting in nitrogen and energy losses (Russel et al. 1992). However, the amount of recycled urea depends on the $\mathrm{N}$-intake: when $\mathrm{N}$ ingestion is low then $\mathrm{N}$ cycling increases, because the urea pool in the metabolism is under physiological homeostatic control, which tends to remain constant (Van Soest 1994).

In the present work, decrease in the relationship between protein and intake of TDN was observed; even without affecting the N-balance, the lower content of metabolizable energy of diets containig StS and, consequently, lower intake of TDN, could result in impaired animal performance. Detmann et al. (2014) showed that the imbalance between energy and protein in diets for cattle affect the $\mathrm{N}$-use efficiency and DM intake, and consequently, cattle performance. However, Castro-Montoya and Dickhoefer (2018) concluded that even though the legume silages in ruminant diets negatively affected DM intake and nutrient digestibility, no negative effects on performance were observed, particularly at legume inclusion levels below $400 \mathrm{~g} /$ $\mathrm{kg}$ DM. Thus, there is still a need for further studies with legume silage for sheep on performance and economic viability.

The constancy on the creatinine excretion may be related to the homogeneity of the sheep body weight. Creatinine is a product of muscle metabolism and their production and excretion is directly related to the metabolism of this tissue (Schutte et al. 1981). Liu and McMeniman (2006), in a study with sheep, reported relative constancy in creatinine excretion for any one diet irrespective of intake level, but affected by animals.

In conclusion, stylo silage had lower content of metabolizable energy in relation to corn silage, resulting in lower intake of TDN in diets for sheep. However, replacing diet $\mathrm{StS}+\mathrm{C}$ by $\mathrm{CS}+\mathrm{C}$ did not affect the nitrogen-use efficiency.

\section{ACKNOWLEDGMENTS}

The authors wish to thank the Conselho Nacional de Desenvolvimento Científico e Tecnológico (CNPq), Fundação de Amparo à Pesquisa do Estado de Minas Gerais (FAPEMIG) and Instituto Nacional de Ciência e Tecnologia - Ciência Animal (INCT-CA) for their financial support.

\section{REFERENCES}

AOAC - ASSOCIATION OF OFFICIAL ANALYTICAL CHEMISTS. 1990. Official methods of analysis. $15^{\text {th }}$ ed., Washington, DC, 1298 p.

BAXTER HD, MONTGOMERY MJ AND OWEN JR. 1984. Comparison of soybean-grain sorghum silage with corn silage for lactating cows. J Dairy Sci 67: 88-96.

CASTRO-MONTOYA J AND DICKHOEFER U. 2018. Effects of tropical legume silages on intake, digestibility and performance in large and small ruminants: A review. Grass Forage Sci 73: 26-39.

CHANEY AL AND MARBACH EP. 1962. Modified reagents for determination of urea and ammonia. Clin Chem 8: 130132.

CHURCH DC. 1979. Digestive Physiology and Nutrition of Ruminants. Vol. 1 - Digestive Physiology. $2^{\text {nd }}$ ed., Oxford Press Inc, $452 \mathrm{p}$.

DETMANN E AND VALADARES FILHO SC. 2010. On the estimation of non-fibrous carbohydrates in feeds and diets. Arq Bras Med Vet Zootec 62: 980-984.

DETMANN E, VALENTE EEL, BATISTA ED AND HUHTANEN P. 2014. An evaluation of the performance and efficiency of nitrogen utilization in cattle fed tropical grass pastures with supplementation. Livest Sci 162: 141153.

FERNANDES C, GROF B, CHAKRABORTY S AND VERZIGNASSI J. 2005. Estilosantes Campo Grande in Brazil: A tropical forage legume success story. In: Proceedings of the $20^{\text {th }}$ International Grassland Congress: Offered papers; 2005; Dublin, Ireland, p. 330-331.

HEINRITZ SN, MARTENS SD, AVILA P AND HOEDTJE S. 2012. The effect of inoculant and sucrose addition on the silage quality of tropical forage legumes with varying ensilability. Anim Feed Sci Technol 174: 201-210.

HUHTANEN P, KAUSTELL K AND JAAKKOLA S. 1994. The use of internal markers to predict total digestibility and duodenal flow of nutrients in cattle given six different diets. Anim Feed Sci Technol 48: 211-227.

KAPS AAND LAMBERSON W. 2004. Biostatistics for animal science. CABI publishing. Cambridge, Massachusetts, 445 p. 
LIU ZJ AND MCMENIMAN NP. 2006. Effect of nutrition level and diets on creatinine excretion by sheep. Small Rumin Res 63: 265-273.

LUCAS HL. 1957. Extra-period latin-square changeover designs. J Dairy Sci 40: 225-239.

MERTENS DR. 1994. Regulation of forage intake. In: Proceedings of the Forage Quality, Evaluation, and Utilization, Wisconsin, USA, p. 450-493.

MERTENS DR. 2002. Gravimetric determination of amylasetreated neutral detergent fiber in feeds with refluxing in beaker or crucibles: collaborative study. J AOAC Int 85 : 1217-1240.

MILLEN DD, PACHECO RDL, ARRIGONI MDB, GALYEAN ML AND VASCONCELOS JTA. 2009. Snapshot of management practices and nutritional recommendations used by feedlot nutritionists in Brazil. J Anim Sci 87: 3427-3439.

MOREIRA JFM, COSTA KAP, SEVERIANO EC, SIMON GA, EPIFANIO PS, CRUNIVEL WS AND BENTO JC. 2015. Production and bromatological composition of cultivars of Brachiaria brizantha and Campo Grande stylo monocropped and intercropped under different planting methods. Afr J Agric Res 10: 317-327.

MUPANGWA J, NGONGONI N, TOPPS J, ACAMOVIC T, HAMUDIKUWANDA H AND NDLOVU L. 2000. Dry matter intake, apparent digestibility and excretion of purine derivatives in sheep fed tropical legume hay. Small Rumin Res 36: 261-268.

NRC - NATIONAL RESEARCH COUNCIL. 2001. Nutrient requirements of dairy cattle. National Academic Press, $7^{\text {th }}$ ed., Washington, DC, $381 \mathrm{p}$.

NRC - NATIONAL RESEARCH COUNCIL. 2007. Nutrient Requirements of Small Ruminants: Sheep, Goats, Cervids, and New World Camelids. National Academic Press, Washington, DC, $362 \mathrm{p}$.

POPPI DP AND MCLENNAN SR. 1995. Protein and energy utilization by ruminants at pasture. J Anim Sci 73: 278290.
ROBERTSON JB AND VAN SOEST PJ. 1981. The detergent system of analysis and its application to human foods. In: James WPT and Theander O (Eds), The analysis of dietary fiber in food. New York: Marcel Dekker, p. 123-158.

RUSSELL JB, O'CONNOR JD AND FOX DJ. 1992. A net carbohydrate and protein system for evaluating cattle diets: I. Ruminal fermentation. J Anim Sci 70: 3551-3561.

SCHUTTE JE, LONGHURST JC, GAFFNEY FA, BASTIAN BC AND BLOMQVIST CG. 1981. Total plasma creatinine: an accurate measure of total striated muscle mass. J Appl Physiol Respir Environ Exerc Physiol 51: 762-766.

SILVA LD, PEREIRA OG, SILVA TC, VALADARES FILHO SC AND RIBEIRO KG. 2016. Effects of silage crop and dietary crude protein levels on digestibility, ruminal fermentation, nitrogen use efficiency and performance of finishing beef cattle. Anim Feed Sci Technol 200: 22-33.

SILVA TC, PEREIRA OG, AGARUSSI MCN, DA SILVA VP, DA SILVA LD, CARDOSO LL, RIBEIRO KG AND VALADARES FILHO SC. 2015. Stylosanthes cv. Campo Grande silage with or without concentrate in sheep diets: nutritional value and ruminal fermentation. Small Rumin Res 126: 34-39.

SILVA TC, PEREIRA OG, MARTINS RM, AGARUSSI MCN, SILVA LD, RUFINO LDA, VALADARES FILHO SC AND RIBEIRO KG. 2017. Stylosanthes cv. Campo Grande silage and concentrate levels in diets for beef cattle. Animal Prod Sci 58: 539-545.

SOUZA WF, PEREIRA OG, RIBEIRO KG, SANTOS SAAND VALADARES FILHO SC. 2014. Intake, digestibility, nitrogen efficiency, and animal performance of growing and finishing beef cattle fed warm-season legume (Stylosanthes capitata plus Stylosanthes macrocephala) silage replacing corn silage. J Anim Sci 92: 4099-4107.

VAN SOEST PJ. 1994. Nutritional Ecology of the Ruminant, $2^{\text {nd }}$ ed., Ithaca (NY): Cornell University Press, 1994, 476 p.

WEISS WP. 1999. Energy prediction equations for ruminant feeds. In: Proceedings of the Cornell Nutrition Conference for Feed Manufacturers; 1999; New York, USA. Cornell University, p. 176-185. 